\title{
A rare presentation of heteropagus conjoined twin: a case report with review of literature
}

\section{Rajshree Dayanand Katke*, Nidhi Sudhakar Kurkal, Tamanna Vinaik, Priyanka Pagare}

Department of Obstetrics \& Gynaecology, Cama and Albless Hospital, Grant Government Medical College and Sir J.J Group of Hospitals, Mumbai, Maharashtra, India

Received: 04 March 2015

Accepted: 19 April 2015

\section{*Correspondence:}

Dr. Rajshree Dayanand Katke,

E-mail: drrajshrikatke@gmail.com

Copyright: ( ) the author(s), publisher and licensee Medip Academy. This is an open-access article distributed under the terms of the Creative Commons Attribution Non-Commercial License, which permits unrestricted non-commercial use, distribution, and reproduction in any medium, provided the original work is properly cited.

\begin{abstract}
Conjoined twins are a rare occurrence with an incidence of about 1 in 100000 pregnancies. Our case is that of a 32 year old multigravida patient who came to us at 17 weeks gestation with a scan done at 14 weeks suggestive of severe spinal dysraphism with lumbar meningomyelocele spina bifida at multiple levels with protuberant abdomen. The patient opted for medical termination of pregnancy which was carried out after due to consent. The patient aborted after 12 hours. Further inspection of the abortus revealed it to be conjoined twins with one apparently normal head and thorax with a large omphalocele with 4 lower limbs. There were two caudal halves along with two sets of lower limbs and external genitalia arising from the abortus perpendicular to it on either side of the thorax. One set of arms was attached to the thorax and yet another arm and a limb bud were arising from the other end of the fetus attached to a rudimentary head like structure. Heteropagus tetrapus twins are an extremely rare form of parasitic twins. Inspite of advances in surgical techniques and methods, the morbidity endured by the affected neonates is very high. Thus prenatal diagnosis of conjoined twins along with the option of termination of pregnancy is of utmost importance.
\end{abstract}

Keywords: Heteropagus, Conjoined twins, Parasitic twins, Prenatal diagnosis

\section{INTRODUCTION}

Conjoined or Siamese twins are the rarest form of monochrionic monoamniotic twins. The incidence of conjoined twins worldwide ranges from 1 in 50000 to 1 in 100,000 with a current prevalence of 1.47 in 100000 births ${ }^{1}$ with a slightly higher incidence in Southwest Asia, Africa and Brazil. ${ }^{2}$ Conjoined twins are usually of the symmetrical variety but at times they may be asymmetrical called heteropagus or parasitic twins. Parasitic twins constitute only $4.5 \%$ of all conjoined twins $^{3}$ of which epigastric heteropagus twins are the rarest of them all. The parasitic twin usually has supernumerary limbs without a functional heart or brain. ${ }^{4}$ The pathogenesis and blastogenesis of parasitic twins is not clearly understood as of yet.

\section{CASE REPORT}

A 32 year old gravida 3 para 2 living 1 death 1 patient came to the out-patient department of Cama and Albess hospital, Mumbai with 17 weeks gestation with a sonogram done at 14 weeks suggestive of spinal dysraphism opting for medical termination of pregnancy. A repeat Sonogram was done at our institute which revealed a fetus with severe spinal deformities. The fetus had lumbar meningomyelocele and spina bifida at multiple levels with lumbar lordosis and a protuberant abdomen. The patient was married since 8 years and had one living female child of 6 years of age followed by an intrauterine fetal demise at full term 2 years back. She had no significant obstetric complications or any major medical or surgical illness in the past. There was no family history of twinning in either parent. General and 
systemic examination was carried out. The patient was vitally stable with a 16 weeks sized uterus per abdomen and per vaginum and a patulous cervical os.

After consultation with the pediatrician as well as the pediatric surgeon, the patient and her husband decided to opt for termination of pregnancy. The patient was admitted and all routine investigations were carried out. The patient's hemoglobin was 10.8 gm $\%$, blood group was B positive and all other investigations were within normal limits. The patient was negative for HIV, hepatitis B, and VDRL. Medical Termination Pregnancy was done with detailed consent. Induction was done with dinoprostone gel followed by injection Pitocin augmentation. The patient aborted after 12 hours uneventfully and completely.

Further inspection of the abortus revealed an apparently normal head with a thorax with two normally formed arms and an omphalocele. The abortus had two caudal ends each with a set of male genitilia and completely formed lower limbs arising laterally from either side of the thorax. One of the caudal ends also had spina bifida. There was yet another arm and a limb bud arising from a rudimentary head like structure at the other end of the fetus. An X-ray was done showing the normal skull of 1 fetus from which arose 1 set of ribs and thoracic vertebrae and two normally formed upper limbs. The lumbar vertebrae continued almost at perpendicular from the right side of the fetus with one set of pelvic bones and completely formed lower limbs with evidence of spina bifida. There was yet another set of lumbar vertebrae, pelvic bones and lower limbs which was fused to the left side of the fetus and one arm arising from the other end of the fetus. There was no evidence of another cranium or thoracic cage. There was a single placenta and cord which did not have any gross abnormalities. The abortus was sent for histopathology which revealed single liver and G-I tract that had herniated into an omphalocele. There was one set of lungs and heart. The parasitic fetus did not have a cranium or thorax and was fused at the epigastrium on left side of the normal fetus.

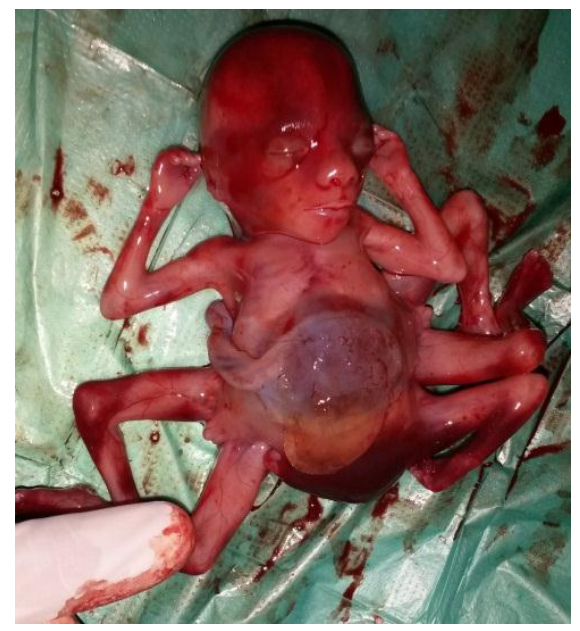

Figure 1: Anterior view of the abortus.

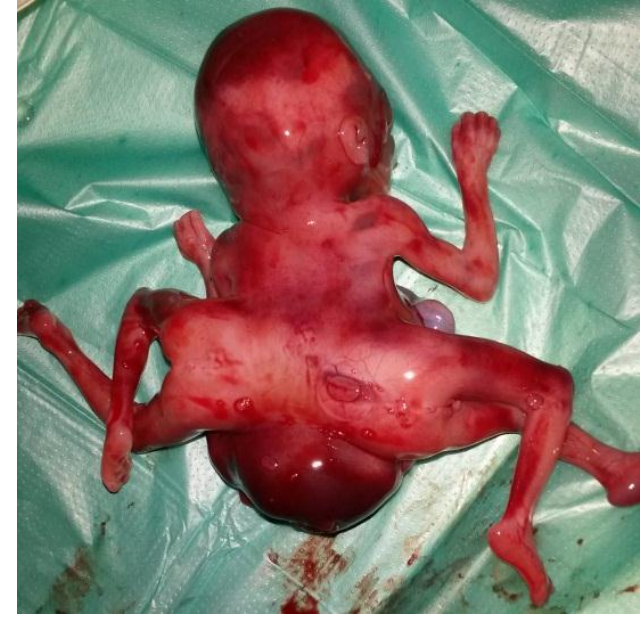

Figure 2: Posterior view of the abortus.

The patient was stable post abortion and was managed with antibiotics. She and her husband refused any further investigations due to financial constraints and she was discharged from the hospital on the third day.

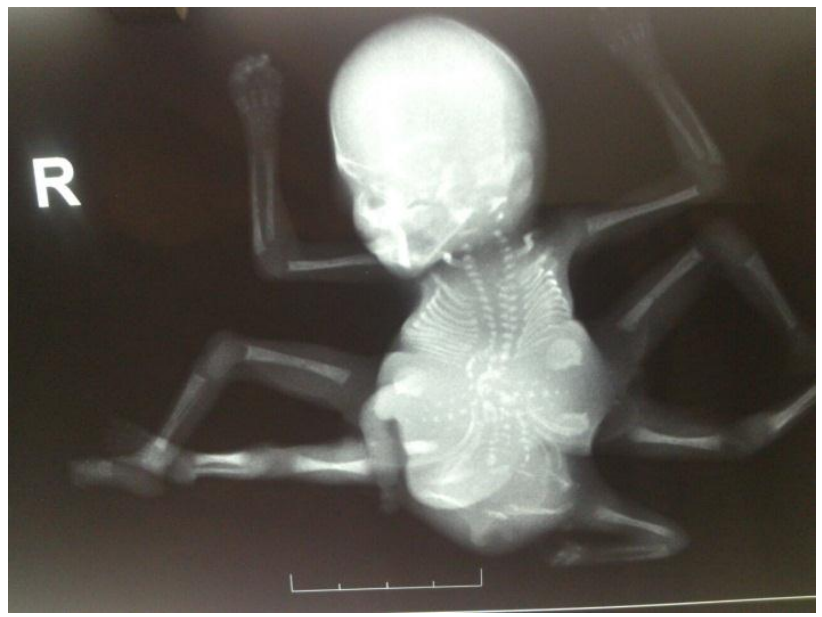

Figure 3: X-ray of abortus; AP view.

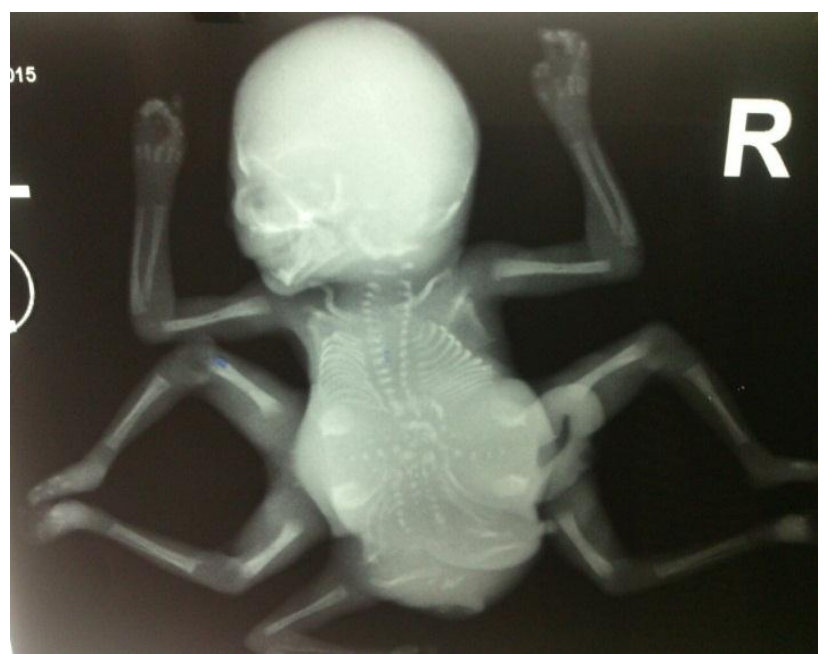

Figure 4: X-ray of the abortus; PA view. 


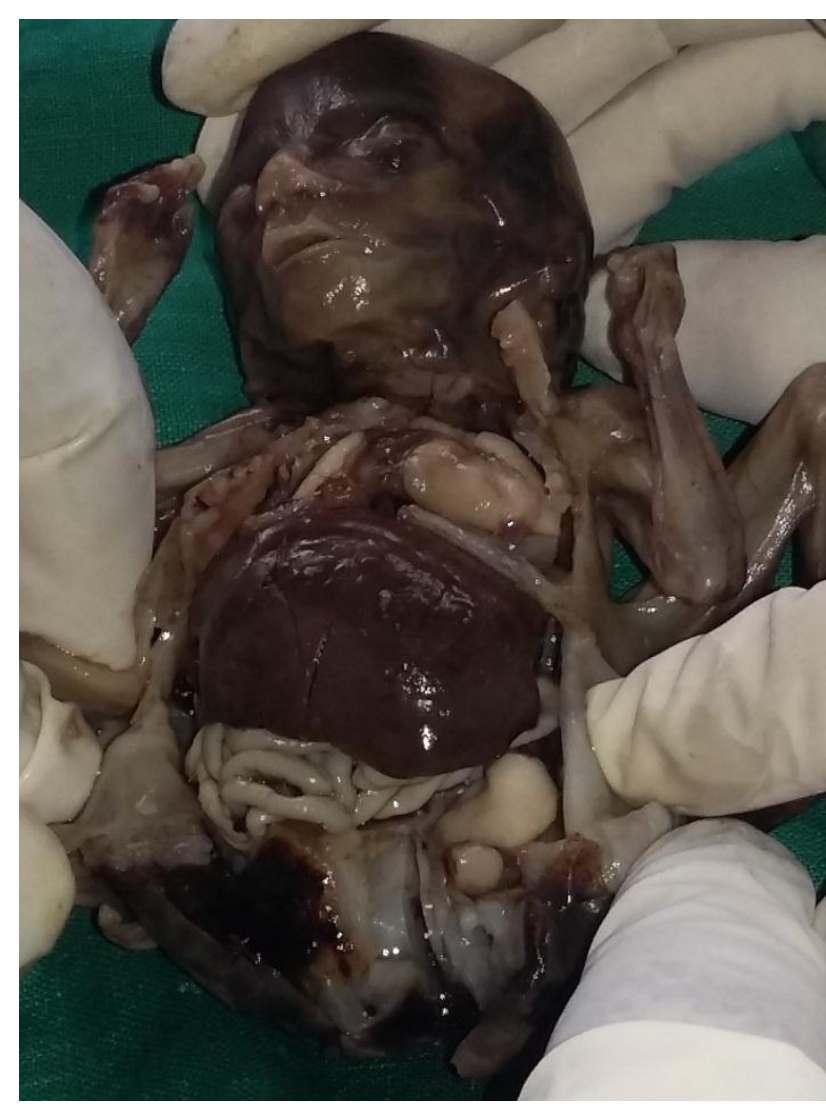

Figure 5: Pathological dissection of the abortus.

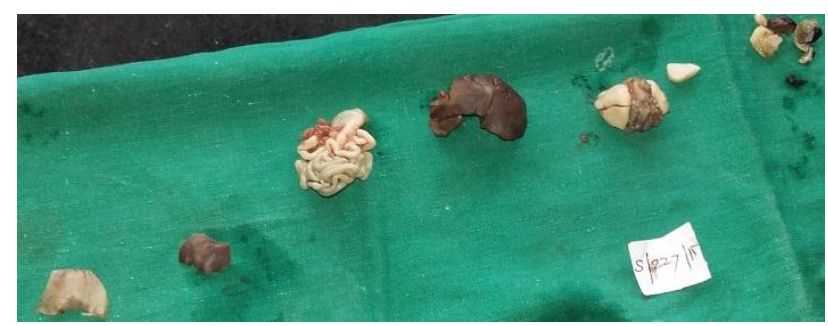

Figure 6: Organs identified from the abortus and sent for histopathology.

\section{DISCUSSION}

The etiopathogenesis of conjoined twins is not clear till today. Although there are two theories of which one is of incomplete fission due to division of the blastocyst beyond the $13^{\text {th }}$ day of fertilization. The other theory which is more accepted today is that of fusion, ${ }^{5}$ in which the fertilized eggs are completely separated but stem cells find like stem cells on the other twin and fuse the twins together. ${ }^{6}$ There have also been reports of conjoined twinning consistent with fusion of two embryos during $\mathrm{IVF}^{7}$ thus recommending cytogenetic testing of all conjoined twins .Conjoined twins maybe symmetrical or asymmetrical. Symmetrical conjoined twins have two identically formed twins which are fused to each other at a certain site on both bodies. They may share viscera at that site and the nomenclature is according to the site of fusion i.e. thoracopagus (fusion at chest; most common variety), omphalopagus (fusion at anterior abdominal wall), pyopagus (Buttocks/sacrum), ischiopagus (Pelvis/ischium), craniopagus (Cranium) or a combination of any of the above such as thoracoompalopagus or ischio-pyopagus.

Asymmetrical conjoined twins are called as heteropagus or parasitic twins in which the 'parasite' is not completely formed and is attached to the normally formed foetus or the 'autosite' at a certain point. The parasite is not completely formed and may only be evident by supernumerary limbs. The spectrum of heteropagus twinning may present depending on the site of union and the extent of damage of one embryo resulting in (1) an externally attached parasitic twin, (2) an enclosed fetus in fetu, (3) an internal teratoma, or (4) an acardiac connected via the placenta. ${ }^{1}$ It is believed that heteropagus twins occur because of some form of ischemic insult in early gestation that leads to selective atrophy and resorption of the cranial part of one of the monozygous twins. Of all the heteropagus twins, epigastric heteropagus twins are among the least documented cases in literature. The parasite usually does not have a functional brain or heart and does not share the host twin's G-I tract or liver but may have a rudimentary G-I tract or Urinary system of its own with connection to that of the host. ${ }^{8}$ Thus surgical separation can be done safely in such patients.

The prenatal diagnosis of conjoined twins is of utmost importance. The diagnosis is usually done by a good sonogram between 14-16 weeks or if necessary an MRI to confirm diagnosis. ${ }^{9}$ However the diagnosis can be completely missed as was in our case where termination was done for other congenital anomalies. The delivery of conjoined twins beyond 20 weeks irrespective of the type is usually done by Caesarean section to avoid invariable obstruction of labour and its complications which will occur if trial of vaginal delivery is given.

\section{CONCLUSION}

The theory behind conjoined twinning is as of yet not understood. Hence it is recommended that all cases of conjoined twins should be reported in literature. There have been numerous case reports and studies of conjoined twins both homopagus and heteropagus twins being delivered at term and undergoing surgical separation of the twins or successful excision of the parasitic twin. However this requires a multidisciplinary approach with good obstetric, anaesthetic, paediatric surgery and NICU setup. Inspite of advances in surgical techniques and resources today, the medical and surgical management of conjoined twins still has chances of great morbidity and mortality to the neonates and also a great financial as well as emotional burden to the parents. Hence early prenantal diagnosis of conjoined twins is of utmost importance and termination of pregnancy should be offered to all affected mothers as an option if detected on time. 
Funding: No funding sources

Conflict of interest: None declared

Ethical approval: Not required

\section{REFERENCES}

1. Spencer R. Parasitic conjoined twins: External, internal (fetuses in fetu and teratomas), and detached (acardiacs). Clin Anat. 2001;14:428.

2. Carnevale FC, Borges MV, Affonso BB, Pinto RA, Tannuri U, Maksoud JG. Importance of angiographic study in preoperative planning of conjoined twins: case report. Clinics (Sao Paulo). 2006;61(2):167-70.

3. Edomonds LD, Layde PM. Conjoined twins in the United States, 1970-1977. Teratology. 1982;37:1118.

4. Cunningham FG, MacDonald PC, Gant NF. Williams's obstetrics. In: Cunningham FG, MacDonald PC, Gant NF, eds. A Book. 23rd ed. New York: McGraw-Hill; 2010.

5. Machin GA. Conjoined twins: implications for blastogenesis. In: Opitz JM, Paul NW, eds.
Blastogenesis: Normal and Abnormal. 9th ed. New York: Wiley-Liss; 1993: 141-75.

6. Le Tao, Bhushan Vikas, Vasan Neil. First aid for the USMLE step 1. In: Le Tao, Bhushan Vikas, Vasan Neil, eds. A Book. 20th Anniversary ed. USA: The McGraw-Hill Companies, Inc.; 2010: 121.

7. Logrono R, Garcia-Lithgow C, Harris C, Kent M, Meisner L. Heteropagus conjoined twins due to fusion of two embryos: report and review. Am J Med Genet. 1997;73:239-43.

8. Abubakar AM1, Ahidjo A, Chinda JY, Tahir C, Abubakar S, Adamu SA, et al. The epigastric heteropagus conjoined twins. J Pediatr Surg. 2011;46(2):417-20.

9. Chen Pei-Lin, Kyuran Ann Choe. Prenatal MRI of heteropagus twins. Am J Roentgenol. 2003;181(6):1676-8.

DOI: $10.18203 / 2320-1770 . i j r c o g 20150108$

Cite this article as: Katke RD, Kurkal NS, Vinaik T, Pagare P. A rare presentation of heteropagus conjoined twin: a case report with review of literature. Int J Reprod Contracept Obstet Gynecol 2015;4:851-4. 